\title{
Peran Kader dalam Sistem Rujukan dan Pencegahan Komplikasi pada Ibu dan Bayi Terhadap Kematian Neonatal
}

\author{
Agustina Widayati ${ }^{1}$, Homsiatur Rohmatin ${ }^{1}$, Umi Narsih ${ }^{1}$ \\ STIKes Hafshawaty Probolinggo, Indonesia ${ }^{1}$ \\ e-mail:oemi_nrs@yahoo.co.id
}

\begin{abstract}
Neonatal mortality is an important concern because it contributes to 59\% of infant deaths. The Birth Planning and Complications Prevention (P4K) Program is still not running optimally because synergy is needed between midwives, mothers, husbands, families, communities and posyandu cadres. The purpose of this study was to analyze the role of posyandu cadres in the application of the referral system and prevention of complications in mothers and infants so as to prevent neonatal death. The design used was a retrospective study with a population of all posyandu cadres in Probolinggo District. The sampling technique used purposive sampling and obtained a sample of 66 posyandu cadres who met the inclusion criteria. Data collection using questionnaires and interviews. Data analysis using chi square test. The results of the study inform that most posyandu cadres lack an active role in the application of the referral system and prevention of complications in mothers and infants, as well as some neonatal deaths. So there is a significant relationship between the role of posyandu cadres in the application of the referral system and the prevention of complications in mothers and infants towards neonatal death
\end{abstract}

Keywords: active, complications, neonatal death, posyandu cadre, referral

\section{Pendahuluan}

Salah satu indikator penentu derajat kesehatan masyarakat adalah Angka Kematian Bayi (AKB). Indonesia merupakan negara dengan AKB yang masih tinggi walaupun secara nasional sudah mengalami penurunan. Persentase AKB salah satunya disumbangkan oleh kematian neonatal (0-28) hari sebesar 59\% sehingga kematian neonatal penting untuk diperhatikan (Kemenkes RI, 2016).

Pada tahun 2016 dan 2017, Dinas Kesehatan Kabupaten Probolinggo mencatat terjadi kematian neonatal sebesar 145 dan 135 (Profil Kesehatan Kabupaten Probolinggo, 2017). Terjadi penurunan kematian neonatal namun masih jauh dari target utama minimal 12 per $1.000 \mathrm{KH}$ pada tahun 2030 yang ditetapkan oleh Sustainable Development Goals (SDGs) 2015.

Program Perencanaan Persalinan dan Pencegahan Komplikasi (P4K) yang merupakan upaya pemerintah dalam menurunkan angka kematian ibu dan bayi baru lahir secara cepat, sampai saat ini penerapannya masih belum optimal. Karena program ini menuntut peran aktif tidak hanya dari bidan tetapi juga dari ibu, suami, keluarga, masyarakat dan kader posyandu.
Sehingga perlu sinergisitas antara semua pihak yang terlibat.

$$
\text { Rohmatin (2018) dalam }
$$

penelitiannya menyampaikan bahwa sebagian besar ibu hamil, suami, keluarga dan masyarakat belum berperan aktif dalam penerapan $\mathrm{P} 4 \mathrm{~K}$ sehingga memberikan sumbangsih terhadap terjadinya kematian neonatal. Salah satu upaya agar ibu hamil, suami, keluarga dan masyarakat berperan aktif dalam penerapan $\mathrm{P} 4 \mathrm{~K}$ adalah dengan meningkatkan peran aktif kader posyandu.

Berdasarkan survei awal dengan metode wawancara kepada 10 kader posyandu pada bulan Juni 2018 di salah satu wilayah di Kabupaten Probolinggo, diperoleh informasi bahwa 70\% kader posyandu belum berperan aktif dalam penerapan $\mathrm{P} 4 \mathrm{~K}$. Masih tingginya kematian neonatal di Kabupaten Probolinggo, yang diakibatkan oleh kurangnya peran aktif ibu, suami, keluarga dan masyarakat dalam penerapan $\mathrm{P} 4 \mathrm{~K}$, juga diduga karena kurangnya peran aktif kader posyandu.

Kader merupakan seorang tenaga sukarela yang direkrut dari, oleh dan untuk masyarakat, yang bertugas membantu kelancaran pelayanan kesehatan khususnya pelayanan kesehatan ibu dan anak. Kader posyandu harus mau bekerja secara sukarela 
dan ikhlas melaksanakan serta menggerakkan masyarakat dalam kegiatan posyandu, jika tidak akan mempengaruhi tingkat keberhasilan program posyandu.

Tujuan dari penelitian ini yaitu mempelajari dampak peran kader posyandu dalam penerapan sistem rujukan dan pencegahan komplikasi pada ibu dan bayi terhadap kematian neonatal.

\section{Metode}

Penelitian ini dilakukan di wilayah Kabupaten Probolinggo. Rancang bangun penelitian adalah restrospective study. Variabel independen dalam penelitian ini adalah peran kader posyandu dalam penerapan sistem rujukan dan pencegahan komplikasi pada ibu dan bayi. Sedangkan variabel dependen dalam penelitian ini adalah kematian neonatal.

\subsection{Metode Pengumpulan Data}

Populasi penelitian adalah seluruh kader posyandu di Kabupaten Probolinggo pada tahun 2018. Teknik sampling menggunakan purposive sampling. Peneliti mengidentifikasi semua karakteristik populasi dengan terlebih dulu melakukan survei awal. Selanjutnya sampel ditetapkan berdasarkan kriteria inklusi yaitu: menjadi kader minimal 5 tahun, berdomisili di wilayah tempat posyandu berada, mengetahui tentang $\mathrm{P} 4 \mathrm{~K}$, dan bersedia menjadi responden. Sampel dalam penelitian ini dihitung dengan rumus pengambilan sampel berjumlah 66 orang. Pengumpulan data menggunakan kuesioner dan wawancara.

\subsection{Metode Analisis Data}

Analisis data menggunakan chi square test dengan $\alpha=0,05$.

\section{Hasil Dan Pembahasan}

Responden dalam penelitian ini adalah para kader posyandu dengan usia mayoritas 30-40 tahun sebesar 53,00\%, pekerjaan ibu rumah tangga $77,30 \%$, dengan tingkat pendidikan SMA 45,50\%. Berikut disajikan hasil penelitian tentang distribusi frekuensi peran kader dalam penerapan sistem rujukan, pencegahan komplikasi pada ibu dan bayi, kejadian kematian neonatal.
Informasi tentang peran kader dalam penerapan sistem rujukan disajikan dalam Tabel 1.

Tabel 1. Distribusi Frekuensi Peran Kader dalam Penerapan Sistem Rujukan

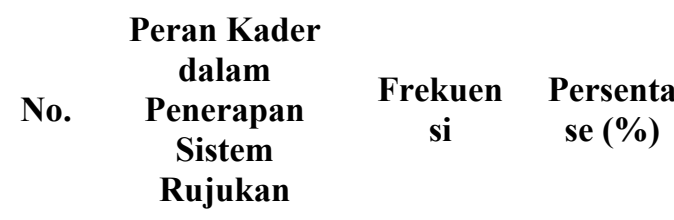

\begin{tabular}{llll}
\hline 1. & Aktif & 26 & 39,4 \\
2. & Tidak Aktif & 40 & 60,6 \\
\hline & Jumlah & $\mathbf{6 6}$ & $\mathbf{1 0 0}$
\end{tabular}

Berdasarkan Tabel 1 diperoleh informasi bahwa sebagian besar kader mempunya peran yang tidak aktif dalam penerapan sistem rujukan $(60,6 \%)$.

Tabel 2 berikut ini menjelaskan tentang peran kader dalam pencegahan komplikasi pada Ibu dan bayi.

Tabel 2. Distribusi Frekuensi Peran Kader dalam Pencegahan Komplikasi pada Ibu dan Bayi

\begin{tabular}{|c|c|c|c|}
\hline No. & $\begin{array}{l}\text { Peran Kader } \\
\text { dalam } \\
\text { Pencegahan } \\
\text { Komplikasi } \\
\text { pada Ibu dan } \\
\text { Bayi }\end{array}$ & Frekuensi & $\begin{array}{c}\text { Persentase } \\
(\%)\end{array}$ \\
\hline 1. & Aktif & 21 & 31,8 \\
\hline 2. & Tidak Aktif & 45 & 68,2 \\
\hline & Jumlah & 66 & 100 \\
\hline
\end{tabular}

Berdasarkan Tabel 2 diperoleh
informasi bahwa sebagian besar kader
mempunyai peran yang tidak aktif dalam
pencegahan komplikasi pada ibu dan bayi
$(68,20 \%)$
Jumlah kejadian kematian neonatal di
Kabupaten Probolinggo ditunjukkan pada
tabel 3.

Berdasarkan Tabel 2 diperoleh informasi bahwa sebagian besar kader mempunyai peran yang tidak aktif dalam pencegahan komplikasi pada ibu dan bayi Jumlah kejadian kematian neonatal di Kabupaten Probolinggo ditunjukkan pada 
Tabel 3. Distribusi Frekuensi Berdasarkan Kejadian Kematian Neonatal

\begin{tabular}{clcc}
\hline No. & $\begin{array}{l}\text { Kematian } \\
\text { Neonatal }\end{array}$ & Frekuensi & $\begin{array}{c}\text { Persentase } \\
(\%)\end{array}$ \\
\hline 1 & Ada & 33 & 50 \\
2 & Tidak ada & 33 & 50 \\
\hline & Jumlah & $\mathbf{6 6}$ & $\mathbf{1 0 0}$ \\
\hline
\end{tabular}

Tabel 3 menunjukkan bahwa dari 66 orang kader yang menjadi responden pada penelitian ini, $50,0 \%$ nya menjawab terjadi kematian neonatal dan 50,0\% nya lagi tidak mengalami kematian neonatal di wilayah kerjanya. Peran kader dalam penerapan sistem rujukan untuk mencegah kematian neonatal disajikan dalam Tabel 4.

Tabel 4. Peran Kader Posyandu dalam Penerapan Sistem Rujukan untuk Mencegah Kematian Neonatal

\begin{tabular}{|c|c|c|c|c|c|c|c|}
\hline \multirow{3}{*}{ No. } & & \multicolumn{4}{|c|}{ Kematian Neonatal } & \multirow{2}{*}{\multicolumn{2}{|c|}{ Total }} \\
\hline & \multirow{2}{*}{$\begin{array}{l}\text { Peran Kader Posyandu dalam } \\
\text { Penerapan Sistem Rujukan }\end{array}$} & \multicolumn{2}{|c|}{ Tidak Ada } & \multicolumn{2}{|c|}{ Ada } & & \\
\hline & & $\mathbf{n}$ & $\%$ & $\mathbf{n}$ & $\%$ & $\mathbf{n}$ & $\%$ \\
\hline 1. & Aktif & 21 & 80,8 & 5 & 19,2 & 26 & 100 \\
\hline \multirow[t]{3}{*}{2.} & Tidak Aktif & 12 & 30 & 28 & 70 & 40 & 100 \\
\hline & Total & 33 & 50 & 33 & 50 & 66 & 100 \\
\hline & \multicolumn{7}{|c|}{$\mathrm{p}=0,000$} \\
\hline
\end{tabular}

Tabel 4 menunjukkan informasi bahwa ada kecenderungan semakin banyak kader posyandu yang tidak berperan aktif dalam penerapan sistem rujukan, maka kematian neonatal juga akan semakin tinggi. Hasil uji statistik chi square diperoleh tingkat signifikansi $(p)=0,000<0,05$. Hal ini menunjukkan ada hubungan yang signifikan antara peran kader posyandu dalam penerapan sistem rujukan dengan pencegahan kematian neonatal.

Informasi hubungan tentang keaktifan kader posyandu dalam pencegahan komplikasi pada ibu dan bayi untuk mencegah Kematian Neonatal disajikan dalam Tabel 5.

Tabel 5. Peran Kader Posyandu dalam Pencegahan Komplikasi pada Ibu dan Bayi untuk Mencegah Kematian Neonatal

\begin{tabular}{|c|c|c|c|c|c|c|c|}
\hline \multirow{3}{*}{ No. } & \multirow{3}{*}{$\begin{array}{c}\text { Peran Kader Posyandu dalam } \\
\text { Pencegahan Komplikasi pada } \\
\text { Ibu dan Bayi }\end{array}$} & \multicolumn{4}{|c|}{ Kematian Neonatal } & \multirow{2}{*}{\multicolumn{2}{|c|}{ Total }} \\
\hline & & \multicolumn{2}{|c|}{ Tidak Ada } & \multicolumn{2}{|c|}{ Ada } & & \\
\hline & & $\mathbf{n}$ & $\%$ & $\mathbf{n}$ & $\%$ & $\mathbf{n}$ & $\%$ \\
\hline 1. & Aktif & 19 & 90,50 & 2 & 9,50 & 21 & 100,00 \\
\hline \multirow[t]{2}{*}{2.} & Tidak Aktif & 14 & 31,10 & 31 & 68,90 & 45 & 100,00 \\
\hline & Total & 33 & 50,0 & 33 & $\mathbf{5 0 , 0}$ & 66 & 100,00 \\
\hline
\end{tabular}




\section{ISSN 2354-5852 \\ e-ISSN 2579-5783}

Berdasarkan Tabel 5 diperoleh informasi bahwa ada kecenderungan semakin banyak kader posyandu yang tidak berperan aktif dalam pencegahan komplikasi pada ibu dan bayi, maka kematian neonatal juga akan semakin tinggi. Hasil uji statistik chi squre diperoleh tingkat signifikansi $(p)=0,000<$ 0,05 . Hal ini menunjukkan ada hubungan yang signifikan peran kader posyandu dalam pencegahan komplikasi pada ibu dan bayi dengan pencegahan kematian neonatal.

Hasil penelitian menginformasikan bahwa sebagian besar kader mempunyai peran yang tidak aktif dalam penerapan sistem rujukan $(60,60 \%)$, dan pencegahan komplikasi pada ibu dan bayi $(68,20 \%)$. Di sebagian wilayah posyandu terjadi kematian neonatal $(50 \%)$.

Ketidakaktifan kader dalam penerapan sistem rujukan menandakan bahwa kader belum secara optimal membantu ibu hamil dan keluarganya untuk mendapatkan kemudahan dalam pelayanan penanganan komplikasi kehamilan, persalinan dan nifas. Terkait dengan peran kader dalam mencegah komplikasi ibu dan bayi, kader juga belum optimal dalam: melakukan pelaporan jika menemui kasus komplikasi ibu hamil dan bersalin kepada tenaga kesehatan, membantu ibu hamil menempel stiker P4K, melakukan kunjungan ke rumah ibu hamil, melakukan pencatatan dan pelaporan tentang kehamilan kepada tenaga kesehatan, meminta Bimtek kepada tenaga kesehatan mengenai KIA dan P4K, memberikan masukan dan saran pada ibu hamil serta keluarganya untuk selalu menjaga kesehatan ibu hamil, memberikan saran kepada pemerintah desa utuk menggerakkan masyarakat dalam memanfaatkan fasilitas kesehatan dengan lebih mudah, serta mengingatkan ibu hamil dan keluarganya untuk memanfaatkan buku KIA.

Kader posyandu sangat berkaitan dengan pelayanan rutin di posyandu. Bekerja secara sukarela dan ikhlas, mau dan sanggup melaksanakan kegiatan posyandu harus dimiliki oleh setiap kader posyandu, serta berkeinginan dan sanggup menggerakkan masyarakat dalam melaksanakan dan mengikuti kegiatan pelayanan di posyandu (Permenkes RI No. 25 tahun 2014, Sulistyorini, C.I dkk, 2010).
Dalam mencegah komplikasi kehamilan kader juga bisa membantu ibu hamil dengan pemeriksaan ANC dan memanfaatkan posyandu dan buku KIA sesuai dengan penelitian Djuhaeni H., Gondodiputro S., \& Suparman R. (2010) dan Tran TK, Nguyen CTK, Nguyen HD, Eriksson B, Bondjers G, Guttvall K, Acher H, \& Petzold M (2011) yang menyatakan bahwa memberikan buku KIA kepada Ibu Hamil dengan cara Ibu dapat memanfaatkan ketika berkunjung ke Posyandu yang berisi perkembangan pelayanan $\mathrm{ANC}$, pemeriksaan kehamilan, TB/BB Bayi, tumbuh kembang anak, pelayanan PNC dan sebagai alat evaluasi dan cross check stiker $\mathrm{P} 4 \mathrm{~K}$ yang dilakukan oleh bidan dan kader ketika kunjungan rumah Ibu. Dengan data dalam stiker, suami, keluarga, kader, dukun, bersama bidan di desa dapat memantau secara intensif keadaan dan perkembangan kesehatan Ibu Hamil, untuk memperoleh pelayanan yang sesuai standar pada saat antenatal termasuk menurunkan angka ketidakcukupan pelayanan K1 sampai K4 (missed opportunity), persalinan dan nifas sehingga proses persalinan sampai nifas termasuk rujukan dapat berjalan dengan aman dan selamat sehingga dapat mencegah kematian Ibu dan Bayi lahir selamat. Hal tersebut menunjukkan bahwa penggunaan buku petunjuk teknis P4K sudah sesuai standar (Depkes RI, 2008).

Widiastuti (2006) cit. Maisya \& Putro (2011) menyatakan bahwa untuk meningkatkan kemandirian kader perlu dilakukan pelatihan, pembekalan kader tentang kegiatan posyandu dan perlunya jadwal yang teratur dalam pelaksanaan kegiatan posyandu. Kader perlu dijelaskan tentang fungsi posyandu dan manfaat bagi kader dan ibu yang memanfaatkan kegiatan posyandu tersebut.

Maisya \& Putro (2011), Pranata, P dan Sugeng (2011) menyatakan bahwa tidak ada kader posyandu yang menggunakan prinsip pemberdayaan sebagai upaya untuk melakukan pemberdayaan. Kegiatan pemberdayaan yang dilakukan posyandu lebih berupaya untuk meningkatkan pengetahuan, bukan cepat mengambil keputusan dan memudahkan akses ke pelayanan kesehatan, membuktikan masih rendahnya penerapan 
pemberdayaan di Posyandu dalam pelaksanaan $\mathrm{P} 4 \mathrm{~K}$.

Kader sebagai tumpuan pemberdayaan masyarakat perlu dibekali pengetahuan yang cukup. Salah satu bentuk operasional yang sangat layak untuk dilaksanakan adalah pelatihan dan penyegaran kader Posyandu. Dari penelitian Mikrajab \& Rachmawaty (2012) menuliskan bahwa setiap kader kesehatan memiliki peran dalam sistem rujukan kasus komplikasi kehamilan masih banyak yang tidak aktif karena kurangnya pengetahuan kader tentang sistem rujukan, menunjukkan data bahwa rujukan ke Puskesmas di atas 50\%. Tetapi, masih terdapat persentase rujukan rata-rata $20 \%$ yang langsung menunjukkan lokasi pelayanan kesehatan rujukan baik pemberi pelayanan kesehatan tingkat 1 , pemberi pelayanan kesehatan tingkat 2 maupun pemberi pelayanan kesehatan tingkat 3 (mulai dari Puskesmas sampai pada RS Rujukan). Dari data tersebut menunjukkan masih belum efektifnya penanganan kasus komplikasi terutama masa kehamilan tidak melalui sistem rujukan berjenjang (referrals system) akibatnya fungsi penapisan kasus komplikasi kehamilan sebagai salah satu cara untuk meningkatkan indikator outcome dalam pelayanan KIA belum bisa berjalan dengan baik.

Selain itu penyebab dari masih banyaknya kematian neonatal yaitu terlambatnya ibu hamil dan suami dalam mengambil keputusan tepat dalam menntukan tempat persalinan. Sehingga perlunya peran aktif kader dalam membantu ibu hamil dalam menentukan tempat bersalin juga sangat membantu bidan memepersiapkan persalinan yang aman. Berdasarkan penelitian Pilkington H, Blondel B, Drewniak N, \& Zeitlin J (2012) menyatakan bahwa sekitar $1 / 3$ dari wanita memilih fasilitas bersalin berdasarkan kedekatan. Proporsi ini meningkat tajam karena suplai yang terbatas. Jarak yang lebih besar antara fasilitas bersalin pertama dan kedua terdekat yang sangat terkait dengan preferensi meningkat untuk kedekatan, lebih dari $85 \%$ perempuan memilih fasilitas terdekat dan lebih dari $70 \%$ melaporkan bahwa kedekatan adalah alasan untuk pilihan mereka.
Peran kader berikutnya yang perlu ditingkatkan adalah mencarikan calon pendonor darah yang tepat bagi Ibu yang membutuhkan darah saat melahirkan di sekitar wilayah kerja Posyandu dengan masyarakat setempat dan memeriksakan golongan darah calon pendonor yang tepat baik di RS PMI setempat atau laboratorium Puskesmas. Kemudian menyiapkan dan men carikan ambulans desa dengan cara gotong royong (swadaya) masyarakat menyiapkan dana untuk memiliki ambulans desa pada saat dibutuhkan untuk kegiatan mobilisasi Ibu Hamil yang akan melahirkan di fasilitas kesehatan (Polindes, Puskesmas perawatan/ PONED) dan tujuan rujukan ke fasilitas kesehatan yang lebih lengkap (RS PONEK).

\section{Simpulan dan Saran \\ 4.1. Simpulan}

Hasil penelitian ini adalah sebagian besar kader belum berperan aktif dalam penerapan sistem rujukan dan pencegahan komplikasi pada ibu dan bayi. Wilayah kerja yang memiliki kematian neonatal adalah sebesar $50 \%$ dari total 66 wilayah. Ada hubungan yang signifikan antara peran aktif kader dalam penerapan sistem rujukan dan pencegahan komplikasi pada ibu dan bayi dengan kejadian kematian neonatal $(\mathrm{p}=000,0)$.

\subsection{Saran}

Saran yang dapat diberikan adalah perlu upaya dalam meningkatkan peran aktif kader antara lain melalui pelatihan dan pendampingan oleh tenaga kesehatan. Bagi masyarakat, diadakan edukasi yang terkait dengan kematian neonatal serta cara mempersiapkan persalinan aman.

\section{Ucapan Terima Kasih}

Ucapan terima kasih disampaikan kepada Kementerian Riset, Teknologi dan Pendidikan Tinggi (Kemenristekdikti) Republik Indonesia atas finansial support bagi kegiatan penelitian ini.

\section{Daftar Pustaka}

Depkes RI. (2008). Pedoman Program Perencanaan Persalinan dan Pencegahan Komplikasi (P4K), Pusat Komunikasi Publik Setjen Depkes. Jakarta. 
Dinas Kesehatan Kabupaten Probolinggo. (2017). Profil Kesehatan Kabupaten Probolinggo Tahun 2016. Probolinggo.

Djuhaeni H., Gondodiputro S., \& Suparman R. (2010). Motivasi Kader Meningkatkan Keberhasilan Kegiatan Posyandu. $M K B, 42(4)$ : 140-8.

Kemenkes RI. (2016). Profil Kesehatan Indonesia Tahun 2016. Jakarta.

Maisya IB, Putro G. (2011). Peran Kader dan Klian Adat dalam Upaya Meningkatkan Kemandirian Posyandu di Provinsi Bali (Studi kasus di Kabupaten Badung, Gianyar, Klungkung, dan Tabanan). Buletin Penelitian Sistem Kesehatan, 14(1): 40-48.

Mikrajab MA \& Rachmawaty T. (2012). Peran Kader dalam program perencanaan persalinan dan Pencegahan Komplikasi PAda Ibu Hamil di Posyandu di Kota Mojokerto, Provinsi Jawa Timur 15(1):365

Peraturan Menteri Kesehatan Republik Indonesia No. 25 Tahun 2014 tentang Upaya Kesehatan Anak.

Pilkington $\mathrm{H}$, Blondel $\mathrm{B}$, Drewniak $\mathrm{N}$, \& Zeitlin J. (2012). Choice in maternity care: associations with unit supply, geographic accessibility and user characteristics. International Journal of Health Geographics, 11; 35.

Pranata, P dan Sugeng. (2011). Pemberdayaan Masyarakat di Bidang Kesehatan, Gambaran Peran Kader Posyandu dalam Upaya Penurunan Angka Kematian Ibu dan Bayi di Kota Manado dan Palangkaraya. Buletin Penelitian Sistem Kesehatan Vol. 14 No.2 April 2011. Jakarta

Rohmatin, H., Widayati, A. (2018). Pengaruh Penerapan Program Perencanaan Persalinan dan Pencegahan Komplikasi (P4K terhadap Kematian Neonatal. JIKES: Jurnal Ilmu Kesehatan. 2(1). P.611.
Sulistyorini, C. I. dkk. (2010). Posyandu dan Desa Siaga. Yogyakarta: Nuha Medika.

Tran TK, Nguyen CTK, Nguyen HD, Eriksson B, Bondjers G, Guttvall K, Acher H, \& Petzold M. (2011). UrbanRural disparities in Antenatal Care Utilization: A study of two cohorts of pregnant women in Vietnam. $B M C$ Health Services Research, 11; 120. 